\title{
Article
}

\section{The role of numeracy skills in graduate employability}

\author{
Durrani, Naureen and Tariq, Vicki
}

Available at http://clok.uclan.ac.uk/2847/

Durrani, Naureen and Tariq, Vicki (2012) The role of numeracy skills in graduate employability. Education and Training, 54 (5). pp. 419-434. ISSN 0040-0912

It is advisable to refer to the publisher's version if you intend to cite from the work.

For more information about UCLan's research in this area go to

http://www.uclan.ac.uk/researchgroups/ and search for < name of research Group>.

For information about Research generally at UCLan please go to

http://www.uclan.ac.uk/research/

All outputs in CLoK are protected by Intellectual Property Rights law, including

Copyright law. Copyright, IPR and Moral Rights for the works on this site are retained by the individual authors and/or other copyright owners. Terms and conditions for use of this material are defined in the policies page.

\section{CLoK}

Central Lancashire online Knowledge www.clok.uclan.ac.uk

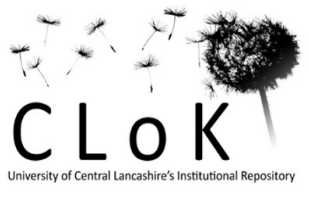




\section{The role of numeracy skills in graduate employability}

\section{Naureen Durrani}

School of Health, Community and Education Studies, Northumbria University, Newcastleupon-Tyne, $U K$

\section{Vicki N. Tariq* School of Social Work and Social Policy, University of Central Lancashire, Preston, UK}

Abstract

Purpose - This article explores the role and importance of numeracy skills in graduate recruitment within a diversity of employment sectors.

Design/methodology/approach - The results of a mixed-methods study, involving three online surveys (including an employer survey), student focus group sessions and interviews with tutors, are presented.

Findings - The results reveal the importance that employers attach to graduates' numeracy skills and the extent to which employers use numeracy tests in graduate recruitment. They thus highlight the potential for poor numeracy skills to limit any graduate's acquisition of employment, irrespective of their degree subject; especially since numeracy tests are used predominantly in recruitment to the types of jobs commensurate with graduates' career aspirations and within sectors that attract graduates from across the diversity of academic disciplines, including the arts and humanities.

Research limitations/implications - Since participants were self-selecting any conclusions and inferences relate to the samples and may or may not be generalisable to wider target populations.

Practical implications - The paper highlights what actions are necessary to enhance undergraduates' numeracy skills in the context of graduate employability.

Social implications - The vulnerability of particular groups of students (e.g. females, those not provided with any opportunities to practise or further develop their numeracy skills whilst in higher education, those with no [or low] pre-university mathematics qualifications, and mature students) is highlighted.

Originality/value - The article is timely in view of national policy to extend the graduate employability performance indicators within quality assurance measures for UK higher education. 
Education + Training (2012): accepted 22 October 2011, in press

1 Keywords - Graduate employability, Numeracy skills, Undergraduates, Graduate skills, UK 2 higher education

3 Paper type - Research paper

4 
Education + Training (2012): accepted 22 October 2011, in press

1

2

3

4

5

6

7

8

9

10

\section{Introduction}

The concept of graduate employability is constructed around a set of complex and diverse skills and personal attributes believed to make an individual more likely to obtain and be successful in employment (Knight and Yorke, 2004). In the UK, the possession of a degree remains a 'threshold requirement', with employers increasingly expecting applicants to possess a variety of personal attributes and generic 'soft' and 'hard' skills (Brown and Hesketh, 2004). Consequently, higher education institutions (HEIs) are now expected to redesign degree programmes and extra-curricular activities to foster undergraduates' employability skills (Knight and York, 2004). Undergraduates too acknowledge the need to enhance their degree credentials through the development of employability skills (Tomlinson, 2008). However, since employers' requirements can change over time, no definitive list of employability skills exists (Knight and Yorke, 2004), making it difficult for HEIs and undergraduates to identify precisely what employers want (Dawson et al., 2006). In addition, the multifarious employability skills initiatives implemented by HEIs do not guarantee the transferability of skills into the workplace (Washer, 2007).

Numeracy skills, recognised as being essential to employability, were amongst the skills Dearing considered "key to the future success of graduates whatever they intend to do in later life" (Dearing, 1997: 133). However, Dearing reported that only one in three graduates felt their numeracy skills had improved whilst in higher education (HE), and he called upon HEIs to do more to produce numerate graduates. Despite this call, in a recent survey of 880 undergraduates from twenty UK HEIs, almost a third (29\%) reported feeling their numeracy skills were inadequate (Confederation of British Industry [CBI], 2009).

Research from the perspective of employers confirms the importance of graduates' numeracy skills. For example, a study by Hoyles et al., (2002) identified that demand from employers for mathematically literate graduates was growing. Numeracy skills were also ranked as the sixth most important (after honesty and integrity, basic literacy skills, basic oral communication skills, reliability, and being hardworking and having a good work ethic), out of a list of twenty-eight employability skills, by $98 \%$ of 500 respondents in an Institute of Directors (IoD) survey (IoD, 2007). Despite the importance attached to numeracy skills, employers of graduates continue to express concerns about the level of numerical competence exhibited by their recruits. For example, $28 \%$ of recruiters expressed concerns about the numeracy skills of graduates (Association of Graduate Recruiters [AGR], 2008) and 21\% of 
employers believed that numeracy skills are only 'occasionally' or 'never' demonstrated by graduates (IoD, 2007).

Despite the importance that employers place upon graduates' numeracy skills, the literature appears unclear about the extent to which numeracy skills influence graduates' procurement of employment, and in which specific numeracy skills employers require their graduate workforce to be competent. This paper bridges this gap by exploring the role that numeracy skills play in graduate recruitment, and the generic numeracy skills employers demand of their graduate employees. It also compares undergraduates' and their tutors' attitudes towards the development of numeracy skills in the context of graduate employability.

\section{Methods}

\subsection{Participants}

Employers invited to participate represented a wide variety of employment sectors (see Table 1) and included those listed by Birchall (2007), the GET 2008 Directory of Graduate Employment and Training (Career Research and Advisory Centre, 2008) and Prospects.ac.uk. Employers were initially contacted by email or telephone, usually via their Human Resources (HR) team, with follow-up communications to encourage participation. In addition, AGCAS (Association of Graduate Careers Advisory Services), AGR, UNITE[1] and the university's Business School Placement Unit helped disseminate the survey via their employer networks.

The target populations of students and tutors represented all undergraduates enrolled at a specific post-1992 UK university in 2008/09 (i.e. 24,595 students) and all academic staff (i.e. 1003) employed at the university during that year. Although all undergraduates and tutors were invited (via emails) to participate and were provided with an explanation of the aims of the study and their respective roles, ethics approval for the study required that participation be on a voluntary basis, with submission of a completed online questionnaire accepted as informed consent; all responses were anonymous. Samples of participating employers, undergraduates and tutors were therefore self-selecting and any conclusions and inferences relate to the samples and may or may not be generalisable to the wider targeted populations.

\subsection{Surveys}

All participants were surveyed using online questionnaires, designed and delivered using Bristol Online Surveys (www.survey.bris.ac.uk). The employers' survey, devised by the 
authors, comprised 16 items; 11 items asked participants to select their answer(s) from the options provided, while five open-ended questions sought further information and invited additional comments. The undergraduate and tutor surveys, although designed to investigate a wide range of issues related to supporting undergraduates' numeracy skills, included six Likert items to gauge respondents' views regarding the potential usefulness of undergraduates' numeracy skills. These items possessed four response options ranging from 'strongly disagree' (1) to 'strongly agree' (4), and were based upon items originally devised by Fennema and Sherman (1976) to assess the usefulness of mathematics, and subsequently modified and used by Tapia and Marsh (2004) and Kadijevich (2006). The undergraduate and tutor surveys also included items aimed at gauging participants' awareness of and familiarity with employers' numeracy tests, and the students' levels of confidence regarding their ability to pass such tests. Demographic information was also collected from respondents. All three surveys, which were piloted with samples of employers (20) undergraduates (140) or tutors (6), are available at www.uclan.ac.uk/information/services/ldu/every_student_counts.php.

\subsection{Focus groups}

Five follow-up focus group sessions were held with 29 volunteer undergraduates, and six individual tutors were interviewed to examine the 'why' behind students' and tutors' responses in the surveys. The focus group and interview schedules followed the themes contained in the questionnaires, but were semi-structured, allowing participants to discuss issues not raised previously. All sessions and interviews (with one exception where permission was denied) were audio-taped and transcribed with the participants' consent.

\subsection{Analyses}

Quantitative data were exported into SPSS v. 17.0 for statistical analyses. Spearman's correlation was used to determine relationships between ordinal variables (i.e. levels of confidence to pass a numeracy test, age and pre-university mathematics qualifications). Gender differences in students' levels of confidence to pass a numeracy test and whether they would like a job involving the use of numeracy skills were explored using Mann-Whitney tests, while differences in these two variables based upon academic disciplines (i.e. faculties) were explored using Kruskal-Wallis tests, followed by post-hoc tests. Differences between tutors' and students' attitudes towards the usefulness of numeracy skills were analysed using Mann-Whitney tests. A chi-square test was used to determine differences, if any, between 
national (UK) and multinational companies in relation to their use of numeracy tests for different types of occupations. Finally, chi-square analyses were carried out to identify the contribution of factors that might explain the variation in employers' use of numeracy tests. All tests were two-tailed.

Qualitative data (focus group/interview transcripts and responses to open-ended questions) were exported into NVivo 2 software for analysis. Thematic analysis, used in analysing qualitative data, involved systematically coding, categorising and identifying key themes within the data through an iterative process.

\section{Results and discussion}

\subsection{Participants}

Employers. The 165 responding companies and organisations were classified according to the system used by Birchall (2007), expanded in light of the Higher Education Statistics Agency's (HESA) Standard Occupational Classification for the Destinations of Leavers from Higher Education Institutions (Davies et al., 2003) (Table I). Employment sectors with the greatest representation and collectively accounting for $59 \%$ of survey returns included consulting firms (12\%), engineering or industrial companies (12\%), banks and financial institutions/services (10\%), local and national government (9\%), IT or telecommunications companies (8\%), and accountancy or professional services firms (8\%) (Table I). Respondents' companies/organisations varied in size with respect to the number of graduates employed, with $49 \%$ employing fewer than 100 graduates, $26 \%$ employing 100-1000, 15\% employing $1001-10000$, and only $10 \%$ of respondents employing more than 10000 graduates.

Respondents also represented companies/organisations based locally within a particular region (15\%), and those possessing a national (30\%) or multinational $(55 \%)$ presence.

Undergraduates and tutors. Table II summarises the demographic characteristics of the 567 undergraduate and 122 tutor respondents, representing response rates of $2.3 \%$ and $12.2 \%$ respectively. The majority of respondents were females from the faculties of Science and Technology or Health and Social Care. Approximately two-thirds (68\%) of student respondents represented second- and third-year undergraduates, in approximately equal proportions, whilst an additional $26 \%$ of respondents represented year one undergraduates; only a very small minority of respondents $(6 \%)$ were enrolled in a foundation year (i.e. year 0 ). The distribution of students' ages reveals that over a third of respondents represented mature, non-traditional undergraduates (i.e. $\geq 30$ years old), reflecting the university's agenda 
1 with regard to widening participation in HE by traditionally under-represented groups of

2 individuals.

3

4 Table I. Employment sectors represented in the sample of responding employers

\begin{tabular}{lc} 
Employment sector & $\begin{array}{c}\text { No. of respondents } \\
(\mathrm{N}=165)\end{array}$ \\
\hline Consulting firm & 20 \\
Engineering or industrial company & 19 \\
Bank or financial institution/services & 17 \\
IT or telecommunications company & 13 \\
Accountancy or professional services firm & 13 \\
Local government & 10 \\
Recruitment/human resources (HR) & 8 \\
Charity or voluntary sector or special interest organisation & 8 \\
Law firm & 5 \\
Healthcare & 5 \\
Teaching & 4 \\
Sales (wholesale and/or retail) & 4 \\
Research and development & 4 \\
National government & 4 \\
Marketing & 4 \\
Armed forces/defence & 4 \\
Travel/transport & 3 \\
Fast-moving consumer goods company & 3 \\
Police & 2 \\
Manufacturing & 2 \\
Chemical or pharmaceutical company & 10 \\
Property development, renting, business or research & 1 \\
Prison service & 1 \\
Mil company & 1 \\
Leisure company & 1 \\
Investment bank & 1 \\
Fashion design & 1 \\
Electricity, gas or water supply & 1 \\
Construction firm & 1 \\
Childcare & 1 \\
\hline & 1 \\
\hline
\end{tabular}

7 numeracy qualifications appear similar for undergraduates and tutors, particularly with regard

8 to qualifications attained at GCSE, AS and A2 levels[2] (or equivalent). However, a greater 
1 proportion of males (24\%) than females (15\%), and students based in Science and

2 Technology (30\%) possessed an AS or A2 in mathematics; such students also tended to be

3 younger $\left(r=-0.38, p<0.001, N=562, R^{2}=0.14\right)$.

4 Table II. Percentage frequency distributions for responding undergraduates and tutors

\begin{tabular}{|c|c|c|}
\hline & $\begin{array}{l}\text { Undergraduates } \\
\qquad(\mathrm{N}=567)\end{array}$ & $\begin{array}{c}\text { Tutors } \\
(\mathrm{N}=122)\end{array}$ \\
\hline \multicolumn{3}{|l|}{ Faculty: } \\
\hline Science and Technology & 28 & 31 \\
\hline Health and Social Care & 34 & 39 \\
\hline Management & 13 & 16 \\
\hline Arts, Humanities and Social Sciences & 23 & 12 \\
\hline $\begin{array}{l}\text { Cross-faculty programmes (i.e. joint or combined } \\
\text { honours degrees) }\end{array}$ & 2 & 2 \\
\hline \multicolumn{3}{|l|}{ Age (years): } \\
\hline $18-19$ & 17 & NA \\
\hline $20-29$ & 48 & NA \\
\hline $30-39$ & 16 & NA \\
\hline $40-49$ & 14 & NA \\
\hline 50 and over & 5 & NA \\
\hline \multicolumn{3}{|l|}{ Gender: } \\
\hline Female & 76 & 61 \\
\hline Male & 24 & 39 \\
\hline \multicolumn{3}{|l|}{ Level of highest mathematics or numeracy qualification:* } \\
\hline No qualification & 15 & 8 \\
\hline CSE & 5 & 8 \\
\hline Adult Numeracy or Key Skills (Application of Number) & 8 & 1 \\
\hline GCSE (or equivalent, e.g. 'O' level) & 55 & 56 \\
\hline AS & 4 & 2 \\
\hline A2 (A level or equivalent) & 13 & 16 \\
\hline $1^{\text {st }}$ degree & NA & 3 \\
\hline Masters degree & NA & 2 \\
\hline Doctorate degree & NA & 4 \\
\hline
\end{tabular}

*Refer to note 2

NA: not applicable

\subsection{Employers' use of numeracy tests in graduate recruitment}

Fifty-one percent of responding employers in the current study claimed to use numeracy tests in graduate recruitment, compared with only $24 \%$ in a recent AGR survey of 242 employers (AGR, 2008); the lower proportion in the AGR survey may reflect the fact that their question concerned the use of only online self-selection/de-selection exercises for candidates, while in 
1 the current survey the question potentially covered the use of paper-based tests as well. Such

2 statistics may reflect employers' continuing disillusionment with formal pre-university

3 mathematics qualifications, particularly at GCSE level, and/or their filtering of unsuitable

4 candidates (Jenkins, 2001). Chi-square analyses revealed that the employers' use of numeracy

5 tests was significantly associated with only two variables, namely size of the graduate

6 workforce and the provision of training in numeracy skills (Table III). Companies recruiting

7 larger numbers of graduates and those providing no additional training in numeracy skills

8 were more likely to use numeracy tests as part of their recruitment processes. Jenkins (2001)

9 and Branine (2008) also reported the increased use of aptitude/psychometric tests (including numeracy tests) by large firms; a finding perhaps reflecting the fact that large firms have more financial resources and expertise at their disposal and a greater number and diversity of vacancies to fill.

Table III. Chi-square analyses of factors potentially influencing employers' use of numeracy tests

\begin{tabular}{|c|c|c|c|c|c|}
\hline $\begin{array}{l}\text { Potential influencing } \\
\text { factor }\end{array}$ & $\begin{array}{l}\text { Pearson Chi- } \\
\text { Square value }\end{array}$ & df & $P$ & $\begin{array}{l}\text { Cramer's V } \\
\text { value }\end{array}$ & $\begin{array}{l}\text { Strength of } \\
\text { association (effect } \\
\text { size) }\end{array}$ \\
\hline Size of graduate workforce & 14.609 & 3 & $0.002 *$ & 0.298 & Medium \\
\hline $\begin{array}{l}\text { Type of company (local v. } \\
\text { national v. multinational) }\end{array}$ & 1.492 & 2 & 0.505 & 0.095 & NS \\
\hline $\begin{array}{l}\text { Minimum mathematics } \\
\text { qualification requirement } \\
\text { (GCSE v. higher } \\
\text { qualification) }\end{array}$ & 0.403 & 1 & 0.597 & 0.055 & NS \\
\hline $\begin{array}{l}\text { Importance attached to } \\
\text { applicants' degree subject }\end{array}$ & 2.245 & 1 & 0.161 & 0.117 & NS \\
\hline $\begin{array}{l}\text { Importance attached to } \\
\text { applicants' degree } \\
\text { classification }\end{array}$ & 4.367 & 1 & 0.050 & 0.163 & NS \\
\hline $\begin{array}{l}\text { Satisfaction with technical } \\
\text { numerical competence }\end{array}$ & 3.735 & 1 & 0.061 & 0.150 & NS \\
\hline $\begin{array}{l}\text { Provision of training in } \\
\text { numeracy skills }\end{array}$ & 6.261 & 1 & $0.017 *$ & 0.195 & Modest \\
\hline $\begin{array}{l}\text { * Significant association betweer } \\
\text { NS }=\text { no significant association }\end{array}$ & e influencing fé & & mployers & se of numerac & \\
\hline
\end{tabular}


1 or only local presence (46\%), the variation was not statistically significant (Table III).

2 However, the lower percentage for multinational companies may reflect the fact that within the current sample these companies possessed higher requirements in terms of applicants' formal mathematics (or -related) qualifications and, therefore, they may have been less reliant on additional tests of their applicants' numeracy skills. For example, $23 \%$ of multinational companies, compared with only $8 \%$ of locally-based and $6 \%$ of national companies, required applicants to possess a mathematics-related first degree. However, 11 out of the 24 companies with only a local presence, representing different employment sectors and requiring different levels of mathematics (or -related) qualifications, reported using numeracy tests, and of these, five employed fewer than 100 graduates, negating any assumption that local companies employing relatively few graduates may be less inclined to use numeracy tests. These statistics reveal the high probability that graduates seeking employment will have their numeracy skills assessed, particularly if the post does not explicitly require applicants to possess a mathematics (or -related) qualification at a level higher than GCSE.

Although numeracy tests play a role in recruitment to all the Standard Occupational Classification (SOC) categories used by HESA (HESA, 2000), they appear to be used predominantly when recruiting to the types of occupations often associated with graduates' aspirations. For example, $29-75 \%$ of employers used numeracy tests when recruiting to professional (75\%), managerial (48\%), administrative (39\%), associate professional and technical (31\%), or secretarial and clerical (29\%) posts, compared with sales and customer service (19\%), skilled trade (14\%) and process, plant and machine operative (10\%) posts. This confirms Jenkins' and Wolf's (2002) observation that, while in the 1990s literacy/numeracy tests were primarily used for clerical posts, by 2001 such tests had been extended to the recruitment of professional (30\%), managerial (25\%) and skilled manual posts (23\%). In the current study, Chi-square analyses revealed no statistically significant differences between national (UK) and multinational companies in relation to the use of numeracy tests in different types of occupations. The current survey also revealed that almost two thirds $(64 \%)$ of organisations use commercially available tests, as opposed to bespoke tests, with Saville and Holdsworth Ltd (SHL) proving to be the most popular commercial provider.

Examples of sectors in which $\geq 60 \%$ of respondents indicated that they use numeracy tests included bank or financial institution/services $(\mathrm{N}=17)$, national and local government $(\mathrm{N}=14)$, and accountancy or professional services $(\mathrm{N}=13)$. This finding has particular 
1 relevance for arts, humanities and social sciences graduates, since many of them will have

2 had little, if any, opportunity to develop and practise their numeracy skills since leaving

3 school, but they will, nevertheless, attempt to enter these employment sectors, believing their

4 first degree provides adequate proof of their skills. In fact, only a third (32\%) of jobs demand

5 a first degree in a specific academic discipline, with this requirement being less prevalent in

6 the banking/finance/insurance, and professional services sectors, where only $16 \%$ and $29 \%$ of

7 jobs respectively have this stipulation (CBI, 2008). The current study revealed that

8 opportunities for undergraduates to develop and/or practise their numeracy skills were far less prevalent in the Arts, Humanities and Social Sciences faculty, where only $16 \%$ of participants (representing 8 out of 15 disciplines) reported their occurrence, compared to the other three faculties (87\% from Science and Technology, representing 14 out of 15 disciplines; $67 \%$ from Management, representing all 5 disciplines; and 63\% from Health and Social Care, representing 4 out of 7 disciplines). Although this finding is not surprising, given that the content of different undergraduate programmes is preparing students for different types of jobs or careers, it nevertheless highlights the importance of providing central support facilities for those students not provided with intra-curricular opportunities to develop and practise their numeracy skills.

With regard to employers' minimum requirements concerning mathematics (or related) qualifications, $48 \%$ of respondents stipulated that graduate applicants should possess at least a GCSE in mathematics or a mathematics-related subject (such as statistics, physics, economics or accounting); these respondents included $\geq 60 \%$ of healthcare organisations, law firms, recruitment and HR organisations, and accountancy and professional services firms. Whilst some organisations were prepared to accept the attainment of a first degree in any discipline as sufficient proof of numerical proficiency,

[Formal mathematics (or -related) qualification] Not always applicable for graduate recruitment - often attainment of the degree is proof of qualification enough. (A respondent representing national government) $17 \%$ of respondents, including consulting firms, engineering or industrial companies and banks or financial institutions, demanded a higher secondary level qualification (e.g. at AS or A2 level), and an additional $16 \%$ of respondents, including IT or telecommunications companies (69\%), engineering or industrial companies (32\%) and banks or financial institutions (18\%) required applicants to possess a first degree in a mathematics (or -related) 
subject. These findings support those of Hoyles et al. (2002), who reported that the type and level of mathematics qualification demanded varied across sectors and the types of post.

The potential for graduates' poor numeracy skills to limit their employment prospects is reinforced by the fact that $70 \%$ of employers considered it 'essential' for applicants to 'pass' their numeracy tests, while the remaining 30\% indicated that it was 'desirable' $(\mathrm{N}=81)$. Although the minimum 'pass' threshold varied and was dependent upon the position and scheme to which candidates applied (e.g. $40 \%$ for 'mainstream' candidates, but over 70\% for applicants on 'fast track' schemes), almost a third (32\%) of all respondents required applicants to achieve a mark of $\geq 60 \%$; sectors represented within this group included bank or financial institutions/services, IT or telecommunications companies, and those involved in research and development: Many graduates are rejected without interview because of poor maths skills. (A respondent representing the banking/financial services sector)

\subsection{Requirements for numerical competency}

When asked to select those numeracy skills in which they would expect their graduate recruits to be competent, only four of the 14 items listed were selected by fewer than $50 \%$ of employers, namely the use of statistical software (25\%), representative sampling (32\%), use of database software (48\%) and understanding the language of maths (48\%), while over $70 \%$ of employers expressed an expectation of competency for eight of the remaining items (Table IV). Consulting firms, IT or telecommunications companies, banks or financial institutions, and engineering and industrial companies expressed the highest demands, with $\geq 60 \%$ of respondents requiring recruits to possess at least ten of the fourteen skills listed (Table IV). Recruitment and HR, and charity or voluntary sector or special interest organisations appeared to be the least stringent in terms of the numeracy skills they expected and were less likely to use a numeracy test; for example, only $38 \%$ and $25 \%$ of respondents from these sectors respectively used numeracy tests. Perhaps not surprisingly, relatively few respondents across the range of sectors required recruits to be proficient in the use of statistical software or representative sampling techniques, since these are specialist skills. 
1 Table IV. Percentage frequency distribution for expectation of graduate competency by

2 responding employers

\begin{tabular}{|c|c|c|c|c|c|c|c|c|c|}
\hline \multirow[t]{2}{*}{ Numerical topics/tasks } & & \multicolumn{8}{|c|}{$\begin{array}{c}\text { Employment sectors (total number of employers } \\
\text { within sector)* }\end{array}$} \\
\hline & 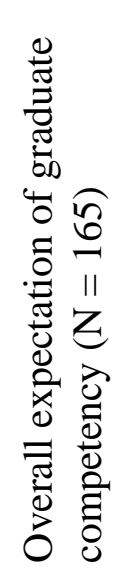 & 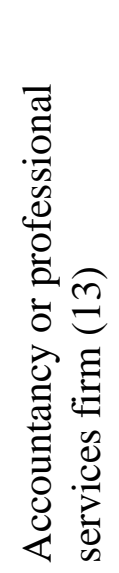 & 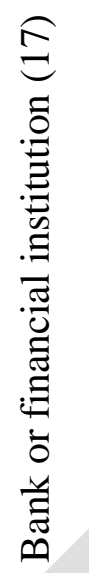 & 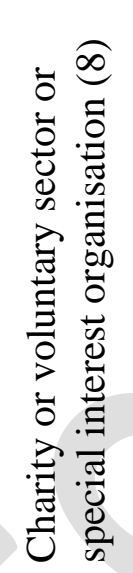 & 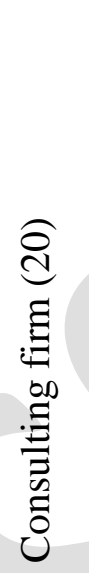 & 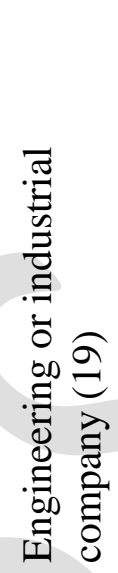 & 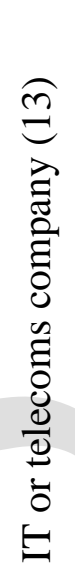 & 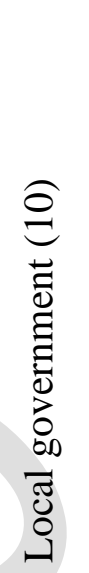 & 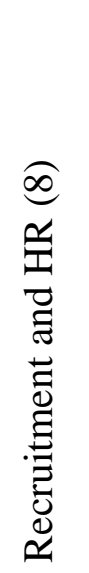 \\
\hline $\begin{array}{l}\text { Understanding the } \\
\text { language of mathematics }\end{array}$ & 48 & 31 & 59 & 13 & 70 & 47 & 62 & 50 & 25 \\
\hline $\begin{array}{l}\text { Understanding the concept } \\
\text { of number }\end{array}$ & 72 & 62 & 77 & 75 & 80 & 84 & 77 & 70 & 38 \\
\hline $\begin{array}{l}\text { Handling fractions and } \\
\text { decimals }\end{array}$ & 74 & 69 & 71 & 50 & 90 & 84 & 77 & 90 & 63 \\
\hline Calculating rates & 73 & 77 & 88 & 50 & 85 & 68 & 77 & 70 & 100 \\
\hline Calculating percentages & 88 & 77 & 94 & 75 & 100 & 95 & 69 & 100 & 88 \\
\hline $\begin{array}{l}\text { Working with ratios and } \\
\text { proportions }\end{array}$ & 73 & 69 & 94 & 50 & 100 & 84 & 62 & 70 & 50 \\
\hline $\begin{array}{l}\text { Understanding measures } \\
\text { of central tendency }\end{array}$ & 56 & 46 & 88 & 50 & 60 & 74 & 62 & 40 & 38 \\
\hline Data interpretation & 85 & 77 & 94 & 88 & 95 & 84 & 85 & 100 & 50 \\
\hline $\begin{array}{l}\text { Numerical problem- } \\
\text { solving }\end{array}$ & 78 & 92 & 100 & 50 & 95 & 90 & 69 & 80 & 38 \\
\hline Representative sampling & 32 & 15 & 41 & 25 & 50 & 42 & 39 & 20 & 13 \\
\hline $\begin{array}{l}\text { Understanding basic } \\
\text { finance }\end{array}$ & 61 & 69 & 71 & 88 & 65 & 42 & 46 & 60 & 75 \\
\hline $\begin{array}{l}\text { Using spreadsheet } \\
\text { software }\end{array}$ & 78 & 85 & 82 & 63 & 85 & 79 & 85 & 80 & 63 \\
\hline Using database software & 48 & 39 & 47 & 25 & 55 & 74 & 85 & 30 & 50 \\
\hline Using statistical software & 25 & 23 & 35 & 0 & 40 & 32 & 46 & 20 & 13 \\
\hline
\end{tabular}


1 Overall, undergraduates and their tutors recognised the importance of numeracy skills in the context of graduate employability and in individuals' everyday lives, although for four of the six Likert items (nos. 1, 3-5), tutors' recognition of the importance of numeracy skills appeared significantly higher than that of the undergraduates (Table V). However, within individual programmes of study, the importance accorded to numeracy skills has to be balanced with regard to the other skills demanded:

As an associate lecturer in English Literature, literacy is my main concern and I have little reason to test the numeracy skills of my students. (English tutor) As mentioned, drug calculations, and basic numeracy, are huge issues within healthcare. Given that patients may die if these are wrong, it is clearly extremely important that ODP and nursing students can demonstrate numerical competency. (Operating Department Practice tutor)

In an additional survey item, only $46 \%$ of students indicated that they would actually like to have a job that involved them applying their numeracy skills, with a significantly higher proportion of males $(61 \%)$ than females $(41 \%)$ expressing this desire $(p<0.001$, Mann-Whitney $U=22949.00, Z=-4.012, r=-0.17)$. Similarly, a greater number of students from Science and Technology (54\%) expressed this desire, compared to students from Management (49\%), Health and Social Care (47\%) and Arts, Humanities and Social Sciences (33\%) (Kruskal-Wallis $H(3)=19.774, p<0.001, N=553)$. However, post-hoc tests revealed that the number of Science and Technology undergraduates expressing this desire was significantly greater only in comparison to undergraduates based in Arts, Humanities and Social Sciences ( $p<0.001$, Mann-Whitney $U=7292.00, Z=-4.365, r=-0.26$ ). What was more surprising was that $54 \%$ of the students surveyed appeared unaware that employers are increasingly using numeracy tests in graduate recruitment; a statistic which could translate into a significant proportion of students being totally unprepared for the types of tests they might encounter when seeking employment. However, it was also apparent that students provided with placement opportunities as part of their undergraduate degrees (e.g. nursing and business programmes) possess a greater awareness of employers' recruitment procedures: Well I'm applying for placements at the minute and I know people who have applied for HR jobs and they've had to do a maths and statistics test online and they've failed it. They've never been asked any question relating to HR yet, but they've been knocked back based on a numerical test. (20-29 year-old female business student) 
Many of the students who participated in focus group discussions were concerned

2 about the increasingly competitive nature of the job market, acknowledging that their

3 numeracy skills would become increasingly important when it came to obtaining a graduate

4 job, even if subsequently they were not required to apply their numeracy skills in the

5 workplace, and believed that adequate preparation for the types of test they might encounter

6 could provide them with an advantage.

7 Table V. Summary of student $(S ; N=567)$ and tutor $(T ; N=122)$ responses to items

8 measuring respondents' perceptions of the usefulness of numerical skills

\begin{tabular}{|c|c|c|c|c|c|}
\hline 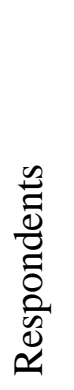 & Item & 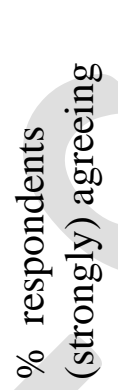 & 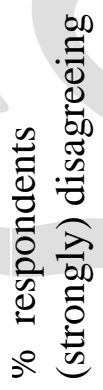 & 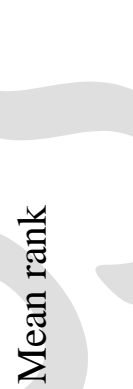 & $P$ \\
\hline $\mathrm{S}$ & $\begin{array}{l}\text { I'll need to be numerically competent if I'm } \\
\text { to gain future employment }\end{array}$ & 84 & 16 & 338.0 & $0.040^{*}$ \\
\hline $\mathrm{T}$ & $\begin{array}{l}\text { Students will need to be numerically } \\
\text { competent if they are going to gain graduate } \\
\text { employment }\end{array}$ & 90 & 10 & 374.6 & \\
\hline$S$ & $\begin{array}{l}\text { It's important that I ensure I have excellent } \\
\text { numerical skills }\end{array}$ & 79 & 21 & 340.2 & 0.126 \\
\hline $\mathrm{T}$ & $\begin{array}{l}\text { It's important that we ensure our students } \\
\text { have excellent numerical skills }\end{array}$ & 82 & 18 & 367.3 & \\
\hline $\mathrm{S}$ & $\begin{array}{l}\text { Numerical skills are important in everyday } \\
\text { life }\end{array}$ & 95 & 5 & 332.2 & $<0.001 *$ \\
\hline $\mathrm{T}$ & $\begin{array}{l}\text { Numerical skills are important in everyday } \\
\text { life }\end{array}$ & 98 & 2 & 402.1 & \\
\hline$S$ & $\begin{array}{l}\text { I feel that improving my numerical skills is } \\
\text { a waste of time }\end{array}$ & 9 & 91 & 357.9 & $<0.001 *$ \\
\hline $\mathrm{T}$ & $\begin{array}{l}\text { I feel that trying to improve students' } \\
\text { numerical skills is a waste of time }\end{array}$ & 5 & 95 & 285.1 & \\
\hline$S$ & $\begin{array}{l}\text { Numerical skills will not be that important } \\
\text { to me in my future employment }\end{array}$ & 14 & 86 & 354.2 & $0.004 *$ \\
\hline $\mathrm{T}$ & $\begin{array}{l}\text { Numerical skills will not be that important } \\
\text { to students in their future employment }\end{array}$ & 5 & 95 & 302.3 & \\
\hline$S$ & $\begin{array}{l}\text { I see my numerical skills as something I } \\
\text { won't use very often once I leave education }\end{array}$ & 15 & 85 & 342.8 & 0.586 \\
\hline $\mathrm{T}$ & $\begin{array}{l}\text { I think that many students won't use their } \\
\text { numerical skills very often once they leave } \\
\text { education }\end{array}$ & 13 & 87 & 352.6 & \\
\hline
\end{tabular}


1 However, $80 \%$ of students responding to the survey reported that they were unfamiliar with 2 the types of numeracy tests employers use. The need to raise student and staff awareness of the use and nature of employers' numeracy tests was reinforced by the finding that although $53 \%$ of tutors claimed to be aware of employers' increasing use of numeracy tests, $81 \%$ were unfamiliar with the types of tests used. There were also some interesting discrepancies between the tutors' and their students' awareness of recruitment procedures, highlighting once again the importance of raising awareness:

Application for employment as a police officer requires the candidate to submit to numeracy tests. Often this one test alone prevents some applicants progressing through the process. (Policing and criminal investigation tutor)

They [employers] are not going to think 'oh they've got into university with no numeracy skills'; they're not even going to ask you. It's just irrelevant because you've got a degree. (20-29 year-old, male policing and criminal investigation student)

Given that $80 \%$ of students were unfamiliar with the types of numeracy tests employers use, it is somewhat surprising that $48 \%$ of respondents were 'moderately confident' or 'very confident' that they could pass such tests. Further analyses revealed variations amongst specific groups of students in terms of their levels of confidence. Male students were significantly more confident than female students ( $p<0.001$, Mann-Whitney $U=21690.00, \mathrm{Z}$ $=-4.681, r=-0.20$ ), although the effect of gender was small, while a higher proportion of students from Science and Technology (57\%) were moderately or very confident, compared to students from the other faculties (37-54\%) (Kruskal-Wallis $H(3)=19.367, p<0.001, N=$ 553). However, post-hoc tests revealed that Science and Technology undergraduates were more confident only in comparison to undergraduates based in Health and Social Care $(U=$ 11514, $p<0.001, N=347, r=-0.20$ ). Perhaps not surprisingly, students possessing higher pre-university mathematics (or -related) qualifications tended to be more confident $(r=0.40$, $\left.p<0.001, N=561, R^{2}=0.16\right)$, as were younger students $\left(r=-0.15, p=0.001, N=565, R^{2}\right.$ $=0.02$ ), possibly because the latter tended to possess higher pre-university mathematics qualifications and/or because, in comparison to many mature students, they had more recently successfully completed a formal mathematics qualification. However, qualification accounted for only $16 \%$ and age for $2 \%$ of the variability in students' expressions of confidence in being able to pass an employer's numeracy test. Discussions with the students confirmed that it may be the lack of any recent opportunity to practise numeracy skills, rather than age per se, that contributes to lower levels of self-confidence: 
Education + Training (2012): accepted 22 October 2011, in press

My course involves a lot of statistics which is pitched at people who have recently completed A-levels. As a mature student I haven't studied statistics for 14 years so am at a disadvantage. (30-39 year old female forensic and investigative sciences undergraduate)

In contrast, mature students with some recent experience of studying for a formal mathematics qualification appeared more confident:

I' $m$ in a better position because I' $d$ just literally sat the GCSE before I came on the course (20-29 year old nursing student).

Although beyond the scope of this paper, a discussion of the strategies students are using to help them develop their numeracy skills, the ways in which tutors are adjusting their practices and the institutional strategies being implemented to help students practise and develop their numeracy skills is provided by Tariq et al. (2010).

\section{Conclusions and implications}

Since all participants in this study were self-selecting volunteers, and were free to withdraw from the project at any time, any conclusions and inferences drawn relate to the samples and may or may not be generalisable to wider target populations. It is also important to note that numeracy skills constitute only one factor that can influence a graduate's procurement of employment, with graduate recruiters also placing substantial emphasis on 'soft', behavioural and interpersonal skills (e.g. team working, initiative, reliability), as well as other 'hard' skills (e.g. literacy, IT) (Brown and Hesketh, 2004). Nevertheless, the data presented highlight the extent to which employers are using numeracy tests as part of graduate recruitment procedures, and draw attention to the potential for poor numeracy skills to limit any graduate's acquisition of employment, irrespective of their academic discipline; especially since the use of such tests appears to be particularly prevalent in recruitment to the types of jobs commensurate with graduates' career aspirations and within sectors that often attract graduates from across the diversity of academic disciplines, including those from the arts and humanities. In addition, the data highlight that four out of five students were unfamiliar with the types of numeracy tests used by employers and that fewer than half the students were confident that they could pass employers' numeracy tests.

Although employers' minimum requirements in terms of a mathematics (or -related) qualification vary, even those setting their minimum requirements at GCSE level may expect their employees to demonstrate a higher level of numerical competency, particularly in certain sectors, once in the workplace. Undergraduates not prepared in advance to successfully meet 
1 these challenges are being placed at a disadvantage, particularly in the UK's current economic 2 climate, where $46 \%$ of graduate recruiters anticipate recruiting fewer graduates (AGR, 2009).

3 Greater access to information on the widespread use of numeracy tests in graduate recruitment and to the range of sample tests available is a first step towards enhancing students' performance in such tests; greater familiarity and practice could also help boost students' confidence.

Recent research suggests that particular groups of students, e.g. female students, students not currently provided with any opportunities to practise and/or further develop their numeracy skills (e.g. as part of their undergraduate programme), students with no (or low) pre-university mathematics (or -related) qualifications, and mature students, may require additional support to help them improve their employment prospects through enhancing their numeracy skills (Tariq et al., 2010; Tariq and Durrani, in press). Some universities will need to do more to provide support (e.g. in the form of centrally-available workshops and/or dropin sessions) to those students requiring additional help to raise the level of their numeracy skills competency. If universities are to enhance their graduates' employment prospects then the numeracy skills required in the workplace must be included amongst the diversity of 'employability skills' universities are expected to nurture. This may require changes in curriculum design and/or the provision of central support facilities and resources (Tariq, et al., 2010). The latter may be particularly important for those undergraduates studying academic disciplines which find it difficult to accommodate numeracy skills within their programmes, e.g. drama or English; such students may have had little or no opportunity to practise and/or further develop their numeracy skills since their compulsory secondary education and, as such, may find employers' numeracy tests particularly challenging.

The results presented are significant in the context of national policy which is determined to link graduate employability to HE quality assurance measures and to require universities to publish data on their graduate employment rates (Department for Business, Innovation \& Skills [BIS], 2011). The current list of performance indicators, which includes the Destination of Leavers from Higher Education (DLHE), will be extended in light of the outcomes of recent government-commissioned research into the information needs of a range of prospective users of information about HE (HEFCE, 2010). Attempting to measure graduate employability by simply measuring institutions' graduate employment rates within a specific time period is problematic, since it views employability as an institutional achievement rather than the ability of the individual graduate to obtain employment (Harvey, 
2001). The latter is, of course, dependent upon a number of factors, in addition to the employability-development opportunities provided by HEIs, including the subject of study, graduates' demographic characteristics (e.g. age, ethnicity, gender, and social class) and work experience, and external economic factors (Harvey, 2001). Nevertheless, changes to national policy should provide additional external drivers for universities to review and improve their strategies with regard to enhancing the employability skills (including numeracy skills) of their students.

While the results of this study suggest that many employers seek graduates with particular kinds and levels of numeracy skills and that many test the possession of the latter via their recruitment procedures, to what extent employers and their graduate employees make use of these numeracy skills subsequently in the workplace and whether and how employees' numeracy skills influence organisational performance warrants further investigation. In addition, future research should evaluate the relative importance of numeracy skills in relation to other employability skills, since graduates' mathematical competencies represent a marker of only one element of their employability, and the question remains as to how mathematical competencies impact upon individuals' longer-term employability.

\section{Acknowledgements}

This research was supported by the National Teaching Fellowship Scheme, funded by the Higher Education Funding Council for England and managed by the Higher Education Academy.

\section{Notes}

1. 'UNITE' is a North West based initiative providing support to small to medium enterprises (SMEs) through four-week undergraduate and graduate placements.

\section{CSEs (Certificates of Secondary Education) and O-levels (ordinary levels) were} qualifications introduced in the 1950s and 1960s and achieved by 16-year-olds at the end of their compulsory secondary level education between these dates and 1987. In 1988, CSEs and O-levels were replaced by GCSEs (General Certificates of Secondary Education). Traditional A-level (advanced level) qualifications were normally awarded to pupils aged 18 years after 2 years' further study of an 'advanced' syllabus. In 2000, Advanced Subsidiary (AS) level and A2-level qualifications were introduced. Pupils may 'cash-in' an AS qualification (after one year of post-16 study) or continue studying the 
subject for a further year to achieve the higher A2 qualification (equivalent to the traditional A-level). Adult Numeracy and Key Skills in 'Application of Number' represent national qualifications that may be attained at a variety of levels; level 2 is regarded as equivalent to a grade $\mathrm{C}$ in GCSE Mathematics.

\section{References}

Association of Graduate Recruiters (AGR) (2008), The AGR Graduate Recruitment Survey 2008. Summer Review, AGR, Warwick.

Association of Graduate Recruiters (AGR) (2009), The AGR Graduate Recruitment Survey 2009. Winter Review, AGR, Warwick.

Birchall, M. (2007), The Times Top 100 Graduate Employers, High Fliers Publications Ltd., London.

BIS (Department for Business, Innovation \& Skills) (2011) Higher Education: Students at the Heart of the System. The UK Government's White Paper on Higher Education. BIS, London, available at: http://discuss.bis.gov.uk/hereform/white-paper/ (accessed 29 June 2011).

Branine, M. (2008), "Graduate recruitment and selection in the UK: a study of recent changes in methods and expectations", Career Development International, Vol.13 No. 6, pp. 497-513.

Brown, P. and Hesketh, A. (2004) The Mismanagement of Talent: Employability and Jobs in the Knowledge Economy, Oxford University Press, King's Lynn.

Career Research and Advisory Centre (2008), GET 2008 Directory of Graduate Employment and Training, Hobsons plc., London.

Confederation of British Industry (CBI) (2008), Taking Stock. CBI Education and Skills Survey 2008, CBI, London.

Confederation of British Industry (CBI) (2009), Future Fit: Preparing Graduates for the World of Work, CBI on Higher Education, CBI, London.

Davies, R., Elias, P. and Ellison, R. (2003), Standard Occupational Classification for the Destinations of Leavers from Higher Education Institutions (SOC[DLHE]), Higher Education Statistics Agency, Cheltenham.

Dawson, I., Jackson, A. and Rhodes, M. (2006), Graduate Skills and Recruitment in the City, City of London and Financial Services Skills Council, London. 
Education + Training (2012): accepted 22 October 2011, in press

1 Dearing, R. (1997), Higher Education in the Learning Society. Report of the National Committee of Inquiry into Higher Education, HMSO, London.

Fennema, E. and Sherman, J.A. (1976), "Fennema-Sherman Mathematics Attitudes Scales: instruments designed to measure attitudes toward the learning of mathematics by females and males", Journal for Research in Mathematics Education, Vol. 7 No. 5, pp. 324-326.

Harvey, L. (2001) "Defining and measuring employability”, Quality in Higher Education, Vol. 7 No. 2, pp. 97-109.

Higher Education Funding Council for England (HEFCE) (2010), “Teaching quality information", available at: www.hefce.ac.uk/learning/qual/tqi.asp (accessed19 May 2010)

Higher Education Statistics agency (HESA) (2000), Standard Occupation Classification (SOC 2000), HESA, Cheltenham.

Hoyles, C., Wolf, A., Molyneux-Hodgson, S. and Kent, P. (2002), Mathematical Skills in The Workplace: Final Report to the Science, Technology and Mathematics Council, Institute of Education, University of London, London.

Institute of Directors (IoD) (2007), Institute of Directors Skills Briefing: Graduates' Employability Skills, IoD, London.

Jenkins, A. (2001), Companies use of Psychometric Testing and the Changing Demand for Skills: A Review of the Literature, Centre for the Economics of Education, London School of Economics and Political Science, London.

Jenkins, A. and Wolf, A. (2002), "Why Do Employers Use Selection Tests? Evidence from British Workplaces", CCE Discussion Paper 27, Centre for the Economics of Education, London School of Economics and Political Science, London.

Kadijevich, D. (2006), "Developing trustworthy TIMSS background measures: a case study on mathematics attitude", The Teaching of Mathematics, Vol. 9 No. 2, pp. 41-51.

Knight, P.T. and Yorke, M. (2004), Learning, Curriculum and Employability in Higher Education, RoutledgeFalmer, London.

Tapia, M. and Marsh, G.E. (2004), “An instrument to measure mathematics attitudes”, Academic Exchange Quarterly, Vol. 8 No. 2, pp. 16-21. 
Education + Training (2012): accepted 22 October 2011, in press

1 Tariq, V. N. and Durrani, N. "Factors influencing undergraduates' self-evaluation of

2

3

4

5

6

7

8

9

10

11

12 numerical competence", International Journal of Mathematical Education in Science and Technology (in press).

Tariq V. N., Durrani, N., Lloyd-Jones, R., Nicholls, D., Timmins, G. and Worthington, C. (2010), Every Student Counts: Promoting Numeracy and Enhancing Employability. University of Central Lancashire, Preston.

Tomlinson, M. (2008), “The degree is not enough: students' perceptions of the role of higher education credentials for graduate work and employability", British Journal of Sociology of Education, Vol. 29 No. 1, pp. 49-61.

Washer, P. (2007), "Revisiting key skills: a practical framework for higher education", Quality in Higher Education, Vol. 13 No. 1, pp. 57-67. 